\title{
HEAT PUMP OPTIMIZATION STRATEGIES FOR PARTICIPATION IN PRICE-CONTROLLED DEMAND RESPONSE IN THE LATVIAN ELECTRICITY MARKET
}

\author{
L. Kurevska \\ Riga Technical University, Power Engineering Institute, \\ 12-1 Azenes Str., Riga, LV-1010, LATVIA \\ E-mail: liga.kurevska@gmail.com
}

Improved end-user engagement is considered to be a key factor in decarbonization efforts towards climate neutral energy systems. While first adopters are already actively seeking ways how to optimize their energy consumption, a true shift in consumer behaviour can only be achieved if the financial benefits are well established and presented.

The study aims at estimating the economic performance of end-user engagement in provision of demand response services using air-to-air heat pumps as the underlying technology. The results of the paper help evaluate in a real data setting whether the existing market framework provides sufficient incentives to facilitate end-user participation in the demand response service.

Keywords: Demand response, electricity price, electricity markets, heat pumps.

\section{INTRODUCTION}

Traditionally, the balance between demand and supply in a power system is maintained by adjusting centrally controlled supply to largely inelastic demand. The increase in intermittent and distributed generation [1] as well as a continuous increase in demand for electricity not only promotes volatility of electricity prices, but also creates new challenges for the power system infrastructure. An aspect of this is illustrated by the case of South Queensland (Australia) where during the period of 2009-2014 the total installed capacity of solar panels increased from $187 \mathrm{MW}$ to $4092 \mathrm{MW}$ [2] and percentage of residential consumers with rooftop solar panels reached $25 \%$. Such a shift reduced electricity volumes consumed through a distribution system 
but did not have considerable impact on the costs of the system, the volume-based distribution system tariffs increased by $112 \%$ [3].

With the emerging preference for electric transportation and heating, the demand for electricity has even more tendency to cluster in high and low demand periods, which may result in peak load demands increasing faster than the total annual consumption and adding additional price pressures to the electricity and power system alike. On the other hand, technologies enabling demand response offer an opportunity to mitigate the volatility of energy consumption patterns, which could help the power system adjust to the emerging and in some cases already established market requirements. The consideration that improving system flexibility is a key factor in reducing the costs of integrating intermittent generation has also been reinforced by recent studies [4]-[6]. For this reason, encouraging consumer engagement in demand response activities has become an increasingly important energy policy topic [4], [7]-[9]. While there might be a discussion on whether facilitation of consumer engagement in the electricity market is necessary, how to achieve that is a challenge with a less clear solution. The objective of this paper is to compare easy-to-use cost optimization scenarios for an air-toair heat pump based heating system. The rest of the paper is organised as followed: Section 2 presents market background and legal framework for the Latvian electricity market. Section 3 is devoted to the examination of contributing factors and barriers for consumer participation in demand response. This review serves as the basis for the case study design, which is described in Section 4. In the last section of the paper, the results of the case study and conclusions are presented.

\section{BACKGROUND AND LEGAL FRAMEWORK}

The EU energy policy foresees increased importance and integration of demand response, facilitated by smart meter rollouts, supportive legal framework and active consumer education. The recital of Council Directive 2019/944/EU (2019) foresees that "[..]Consumers should have the possibility of participating in all forms of demand response. They should therefore have the possibility of benefiting from the full deployment of smart metering systems and, where such deployment has been negatively assessed, of choosing to have a smart metering system and a dynamic electricity price contract. This should allow them to adjust their consumption according to realtime price signals that reflect the value and cost of electricity or transportation in dif- ferent time periods, while Member States should ensure the reasonable exposure of consumers to wholesale price risk. Consumers should be informed about benefits and potential price risks of dynamic electricity price contracts [...]". In its turn, Article 11 stipulates that "Member States shall ensure that the national regulatory framework enables suppliers to offer dynamic electricity price contracts. Member States shall ensure that final customers who have a smart meter installed can request to conclude a dynamic electricity price contract with at least one supplier and with every supplier that has more than 200000 final customers" [10]. According to CEER in 2018, 21 out of 27 Member States offered some type of variable price contracts and 
only in 15 out of 27 Member States spotprice tied contracts were available to residential users [11].

Electricity market liberalization started in Latvia in 2007 when the option to freely choose an electricity supplier was offered to business consumers with high consumption. Furthermore, such an opportunity was offered to business consumers with medium consumption on 1 April 2012 and to all other business consumers on 1 November 2012. The market was opened to residential consumers on 1 January 2015. While the electricity suppliers in Latvia are required to offer a "universal product" to residential consumers, the Latvian legal framework does not require electricity suppliers to offer dynamic electricity price contracts. According to the data published by the Public Utilities Commission of Latvia, $12.5 \%$ (a three-fold increase from the end of 2017) of residential consumers and $42.8 \%$ of business consumers $(\sim 30 \%$ increase from the end of 2017) chose a dynamic pricing type of contract (Figs. 1 and 2) [12]. Currently, most of electricity suppliers provide some type of dynamic price contracts (either time-of-use [13] or spot-price tied [14]) to both business and residential consumers.

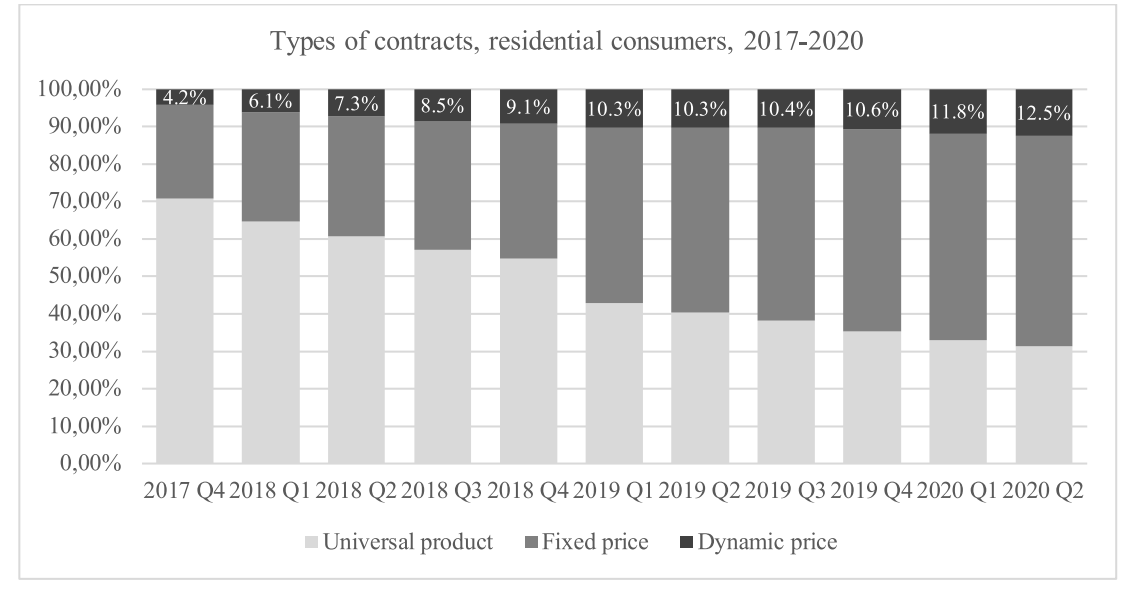

Fig. 1. Contract type structures for residential consumers in Latvia, 2017-2020. Data source: [11].

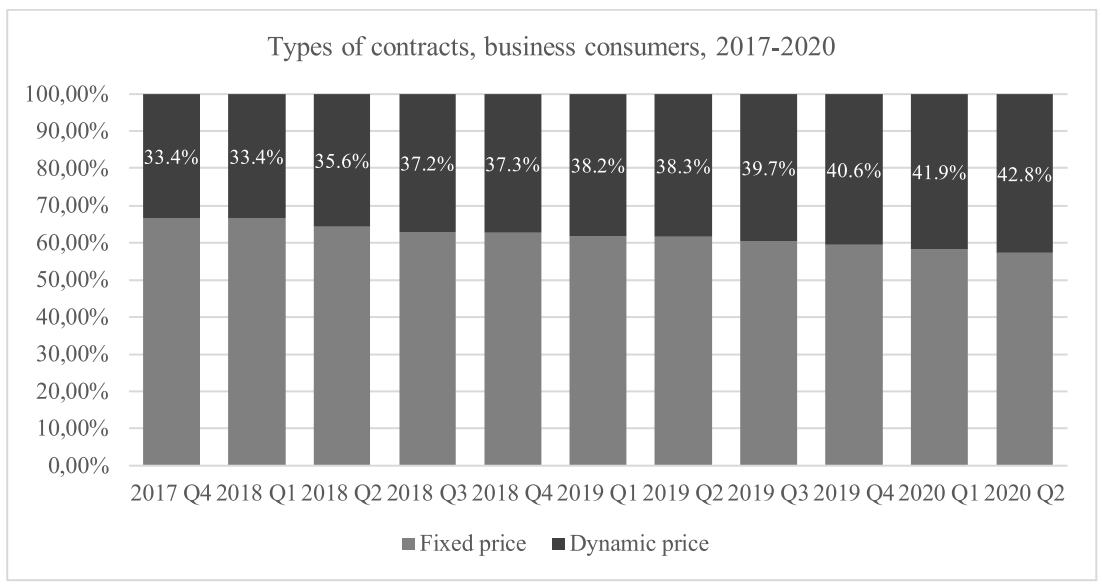

Fig. 2. Contract type structures for business consumers in Latvia, 2017-2020. Data source: [11]. 
To look at overall consumption pattern trends in Latvia, the year 2020 is excluded due to a considerable, but not easily measurable impact of pandemic. By comparing day-ahead market volumes for 2017 and 2019, it can be observed that while the overall volumes increased the volatility of the volumes bought decreased (see Table 1) [15]. Despite a positive trend, more research should be conducted to explore the drivers behind it. The data also show high variations between peak and off-peak demand and a potential for an implicit demand response to facilitate it.

Table 1. Comparative Descriptive Statistics for Energy Volumes Sold on NordPool Day-Ahead Market in 2017 and 2019 [14]

\begin{tabular}{|c|c|c|c|}
\hline Parameter & 2017 & 2019 & Deviation \\
\hline Sum & $7.2 \mathrm{TWh}$ & $7.3 \mathrm{TWh}$ & $+0.7 \%$ \\
\hline Mean & $828 \mathrm{MWh}$ & $834 \mathrm{MWh}$ & $+0.7 \%$ \\
\hline Standard deviation & $177 \mathrm{MWh}$ & $167 \mathrm{MWh}$ & $-5.9 \%$ \\
\hline Range & $828 \mathrm{MWh}$ & $742 \mathrm{MWh}$ & $-10.4 \%$ \\
\hline Minimum volume & $444 \mathrm{MWh}$ & $479 \mathrm{MWh}$ & $+7.9 \%$ \\
\hline Maximum volume & $1272 \mathrm{MWh}$ & $1222 \mathrm{MWh}$ & $-4.0 \%$ \\
\hline
\end{tabular}

\section{BARRIERS FOR CONSUMER ENGAGEMENT IN DEMAND RESPONSE}

Residential consumer engagement (or lack of it) can be divided into stages, each characterised with different preconditions. EPRI (2012) proposes the following three-step structure: participation (being enrolled in demand response), performance (responding in the desired way) and persistence of effects over time (Fig. 3) [4], [16].

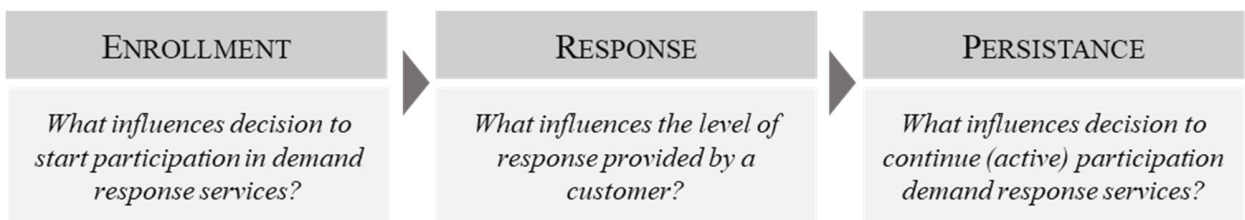

Fig. 3. Three stages of consumer engagement in demand response. Adapted from [3].

Understanding the barriers and drivers of long-term active participation in demand response can allow policy makers and market actors to identify and foster consumer engagement in a more cost-effective way and assess the potential for demand side response participation in a more precise manner.

Parrish et al. (2020) identified the following types of motivators: financial, environmental and social. Based on multiple studies, the financial incentives are the most important [4], [17]-[23]. Financial incentives include reduced monthly bill, rewards for specific consumption patterns, free or reduced cost technology [4]. Environmental motivators are less studied and seem to play a less important role as participation in demand response does not necessarily decrease the overall consumption [4], [24]. Social motivators include increased perceived control over energy consumption 
[17], [24], finding the experience novel and entertaining [17] or taking pride in being socially responsible or supportive to the energy system [4], [25], [26].

These benefits or motivators are usually weighed against effort, time, conve- nience, and comfort [4], [27]-[29]. Based on the systemic review by [4], real financial benefits serve as a necessary precondition for meaningful participation in implicit demand response activities.

\section{CASE STUDY DESIGN}

Heating, ventilation, and air conditioning (HVAC) systems have a tendency in developed countries to become more prevalent over time [30]. For example, in Latvia, $6 \%$ of residential buildings had electricity-based heating and $\sim 2 \%$ of residential buildings had air conditioning in 2015 [31]. It should be noted that HVAC tends to be one of the most energy intensive residential types of electric appliances. The exact estimation for the proportion of electricity consumption for which HVAC is responsible is hard to come by as these estimates will differ on climate, building and other appliances. On average, it is considered that heating is responsible for up to $50 \%$ of the monthly electricity consumption during a peak demand period [32].

By reviewing the existing literature on HVAC control system testing and designing, it can be observed that while there are different energy efficiency objectives or particular challenges of multi-building or multi-zonal systems, a general approach to introducing deterministically controlled HVAC system is fairly simple and requires data collection, algorithm and load controller device [32]-[35]. The objective of this study is to evaluate in a real data setting the most appropriate algorithm for implementing automatic and cost-efficient HVAC system management that relays on publicly available data. To achieve the objective for the set period of time (in December 2020 and January 2021), four HVAC systems were monitored. Afterwards, alternative optimization approaches were tested. The best performing algorithm is further intended to be used for HVAC management. Table 2 and 3 present the case study environment and describe the data used, respectively.

Table 2. Description of the Case Study Environment

\begin{tabular}{|l|l|}
\hline $\begin{array}{l}\text { HVAC } \\
\text { systems used }\end{array}$ & $\begin{array}{l}\text { One Toshiba Premium air-air type of heat pumps (RAS-25PAVPG-ND), with heating } \\
\text { capacity of } 0.7-6.70 \mathrm{~kW} \text { and three Toshiba Optimum (RAS-25PKVSG-ND) heat pumps } \\
1.00-6.50 \mathrm{~kW} \text { were chosen }\end{array}$ \\
\hline Area & $\begin{array}{l}\left.\text { Two isolated rooms of } 26 \mathrm{~m}^{2} \text { (set indoor temperature of } 17^{\circ} \mathrm{C}\right) \text { and } 23 \mathrm{~m}^{2} \text { (set indoor } \\
\left.\text { temperature of } 17^{\circ} \mathrm{C}\right) \text { and a large hall of } 70 \mathrm{~m}^{2} \text { (set indoor temperature of } 19^{\circ} \mathrm{C} \text { with } \\
\text { some HVAC unrelated temperature fluctuations due to ventilation or use of other devices) }\end{array}$ \\
\hline Period & 24 days, December 2020 -January 2021 \\
\hline
\end{tabular}

Table 3. Description of the Data Used in the Case Study

\begin{tabular}{|l|l|}
\hline $\begin{array}{l}\text { Outside } \\
\text { temperature }\end{array}$ & $\begin{array}{l}\text { Factual hourly data from metrological data from the Latvian Environment, Geology and } \\
\text { Meteorology Centre }\left({ }^{\circ} \mathrm{C}\right)[35]\end{array}$ \\
\hline Day-ahead prices & Factual hourly data from NordPool exchange (EUR/MWh) [15] \\
\hline Heat pump load & Measured every minute (MW) \\
\hline
\end{tabular}


In the context of this study, the following assumptions (simplifications) were made - firstly, the load was only shifted and there was no reduction of total consumption (rebound effect expected to be $100 \%$ ). The consumption from the hour when the system is turned off is shifted to the next two hours. The determination of the exact nature of the rebound effects in different condi- tions is outside the scope of this study and is left for further research. This assumption prescribes that switching off may not occur more often than once every two hours (the condition is also observed during the date change).

The following optimization scenarios were devised (Table 4).

Table 4. Optimization Scenarios Used in the Case Study

\begin{tabular}{|c|c|c|}
\hline Scenario & Conditions & Objective \\
\hline \multicolumn{3}{|c|}{$\begin{array}{l}\text { Selecting two hours in every given day, when the HVAC is switched off, } \\
\text { is based on the following criteria: }\end{array}$} \\
\hline $2-1$ & The lowest temperature & $\begin{array}{l}\text { Representation of the highest expected } \\
\text { consumption [36] }\end{array}$ \\
\hline $2-2$ & The highest day-ahead price & Representation of the highest cost per MWh \\
\hline $2-3$ & $\begin{array}{l}\text { The highest projected cost savings from load } \\
\text { shifting }\end{array}$ & $\begin{array}{l}\text { Representation of the highest total gains from } \\
\text { shifted consumption }\end{array}$ \\
\hline \multicolumn{3}{|c|}{$\begin{array}{l}\text { Selecting three hours in every given day, when the HVAC is switched off, } \\
\text { is based on the following criteria: }\end{array}$} \\
\hline $3-1$ & The lowest temperature & $\begin{array}{l}\text { Representation of the highest expected } \\
\text { consumption }\end{array}$ \\
\hline $3-2$ & The highest day-ahead price & Representation of the highest cost per MWh \\
\hline $3-3$ & $\begin{array}{l}\text { The highest projected cost savings from load } \\
\text { shifting }\end{array}$ & $\begin{array}{l}\text { Representation of the highest total gains from } \\
\text { shifted consumption }\end{array}$ \\
\hline
\end{tabular}

The highest projected costs savings $\left(\mathrm{C}_{\mathrm{H} 0}\right)$ from load shifting were calculated as follows:

$C_{H 0}=E_{H 0} \times P_{H 0}-E_{H 0} \times \frac{P_{H 1}+P_{H 2}}{2}$,

where

$\mathrm{C}_{\mathrm{H} 0}$ - expected costs savings from load shifting (EUR);

$\mathrm{E}_{\mathrm{H} 0}$ - energy volume shifted from hour $\mathrm{H}_{0}$ to hour $\mathrm{H}_{1}$ and $\mathrm{H}_{2}(\mathrm{MWh})$;

$\mathrm{P}_{\mathrm{H} 0}, \mathrm{P}_{\mathrm{H} 1}, \mathrm{P}_{\mathrm{H} 2}-$ day-ahead price for hour $\mathrm{H}_{0}$, hour $\mathrm{H}_{1}$, hour $\mathrm{H}_{2}$, respectively (EUR/MWh)
$E_{H 0}=0.001288-0.00015 T_{H 0}$,

The expected energy volume $\mathrm{E}_{\mathrm{H} 0}$ shift was calculated based on the empirically obtained relationship for a particular HVAC system:

where

$\mathrm{T}_{\mathrm{H} 0}$-expected temperature at hour $\mathrm{H}_{0}\left({ }^{\circ} \mathrm{C}\right)$.

The empirical equitation (Fig. 4) was obtained by applying linear regression to the empirical consumption and factual temperature data from the case study. 


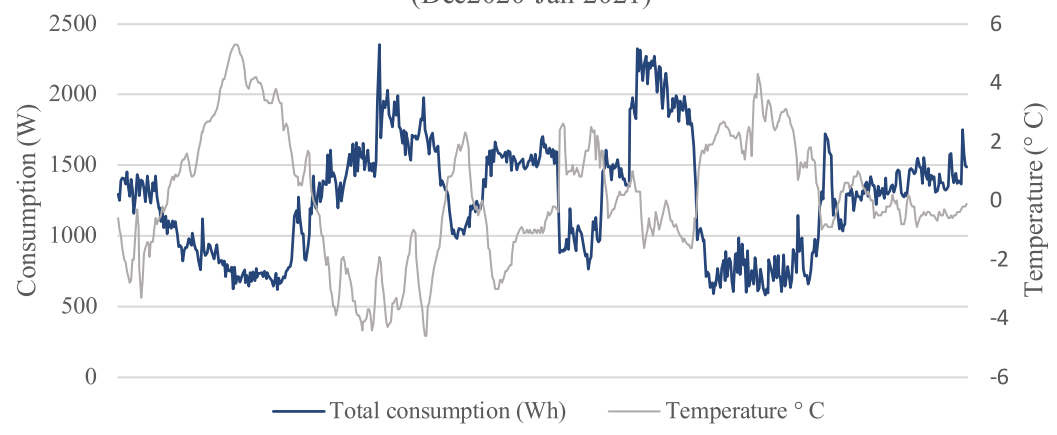

Fig. 4. Hourly HVAC consumption and temperature data during the study. Temperature data source [34].

The optimization algorithm selects the best fit based on the conditions described above. In case the best fit violates the con- dition that HVAC may only be switched off no more often than once every three hours, the next best fit is selected.

\section{RESULTS AND CONCLUSIONS}

During the observation period the following data were collected in regard to outdoor temperature, day-ahead price and actual HVAC consumption (Table 5).

Table 5. Descriptive Statistics of Temperature, Electricity Price and HVAC Consumption during the Case Study. Data sources - temperature [34], electricity prices [14]

\begin{tabular}{|l|c|c|c|}
\hline Parameter & $\begin{array}{c}\text { Temperature } \\
\left({ }^{\circ} \mathrm{C}\right)\end{array}$ & $\begin{array}{c}\text { Day-ahead price } \\
(\text { EUR/MWh })\end{array}$ & $\begin{array}{c}\text { HVAC actual } \\
\text { consumption }(\mathrm{kWh})\end{array}$ \\
\hline Mean & 0.1 & 43.89 & 1.26 \\
\hline Range & 9.9 & 197.21 & 1.77 \\
\hline Minimum & -4.6 & 2.75 & 0.58 \\
\hline Maximum & 5.3 & 199.96 & 2.36 \\
\hline
\end{tabular}

The scenarios previously described provide the following outcomes (Table 6).

Table 6. Optimization Scenario Output Comparison

\begin{tabular}{|l|l|l|l|l|l|l|}
\hline Scenario & $\begin{array}{l}\text { \# of hours } \\
\text { selected per } \\
\text { day }\end{array}$ & $\begin{array}{l}\text { Total } \\
\text { consumption } \\
(\mathrm{kWh})\end{array}$ & $\begin{array}{l}\text { Total cons. } \\
\text { shifted }(\mathrm{kWh})\end{array}$ & $\begin{array}{l}\text { Percentage of } \\
\text { cons. shifted }\end{array}$ & $\begin{array}{l}\text { Total cost of } \\
\text { electricity } \\
(\text { EUR })\end{array}$ & $\begin{array}{l}\text { Cost difference } \\
\text { from base } \\
\text { scenario }\end{array}$ \\
\hline Base & $0 \mathrm{~h}$ & 748.42 & - & - & 33.58 & - \\
\hline $2-1$ & $2 \mathrm{~h}$ & 748.42 & 70.94 & $9.5 \%$ & 33.58 & $0.01 \%$ \\
\hline $2-2$ & $2 \mathrm{~h}$ & 748.42 & 65.37 & $8.7 \%$ & 32.94 & $-1.90 \%$ \\
\hline $2-3$ & $2 \mathrm{~h}$ & 748.42 & 67.42 & $9.0 \%$ & 32.18 & $-4.18 \%$ \\
\hline $3-1$ & $3 \mathrm{~h}$ & 748.42 & 104.64 & $14.0 \%$ & 33.54 & $-0.13 \%$ \\
\hline $3-2$ & $3 \mathrm{~h}$ & 748.42 & 97.36 & $13.0 \%$ & 32.68 & $-2.69 \%$ \\
\hline $3-3$ & $3 \mathrm{~h}$ & 748.42 & 99.43 & $13.3 \%$ & 31.97 & $-4.81 \%$ \\
\hline
\end{tabular}


The relative performance of the scenarios was similar in both two-hour and threehour scenario groups. The highest load shift was observed in a scenario where the load was shifted away from the coldest hours (in a two-hour scenario $-9.5 \%$ of total load was selected, while in a three-hour scenario $14.0 \%$ of load was shifted). However, neither scenario 2-1 nor 3-1 resulted in noticeably different total costs regarding the base case scenario. This might be related to the following: the coldest hours are typically during the night when the electricity price dynamic is less pronounced. Scenarios 2-2 and 3-2 in both two-hour and three-hour groups demonstrated similar relative performance in their scenario groups; however, the best performing scenario was 2-3 and 3-3 that considered both the expected difference in price and the expected loads. The improved economic performance over scenario 2-2 and 2-3 is considerably higher than the increased load shift. This indicates that a sub-optimal choice is considering day-ahead prices and not taking into account the expected consumption level.

Overall, results of the case study suggest that the immediate benefits from load-shifting are modest. Taking this into account, if the energy policy maker considers and identifies that active engagement of residential consumers in implicit demand response activities is pivotal for better integration of intermittent and distributed generation as well as power system optimization, additional incentives reflecting overall system benefits from more moderate peak and off-peak loads might be considered.

\section{ACKNOWLEDGEMENTS}

The research has been supported by the Ministry of Economics of the Republic of Latvia, project "Future-Proof Development of the Latvian Power System in an Integrated Europe (FutureProof)", project
No. VPP-EM-INFRA-2018/1-0005 and by the Latvian Council of Science, project "Management and Operation of an Intelligent Power System (I-POWER)" (No. lzp2018/1-0066).

\section{REFERENCES}

1. Sauhats, A., Zemite, L., Petrichenko, L., Moshkin, I., \& Jasevics, A. (2018). Estimating the Economic Impacts of Net Metering Schemes for Residential PV Systems with Profiling of Power Demand, Generation, and Market Prices. Energies, 11 (11). doi:10.3390/en11113222

2. The International Energy Agency. (2020). National Survey Report of PV Power Applications in Australia 2019. Available at https://iea-pvps.org/wp-content/uploads/ 2020/09/NSR_Australia-2019.pdf

3. Simshauser, P. (2016) Distribution Network Prices and Solar PV: Resolving Rate Instability and Wealth Transfers through
Demand Tariffs. Energy Economics, 54, 108 122.

4. Parrish, B., Heptonstall, P., Gross, R., \& Sovacool, B. K. (2020). A Systematic Review of Motivations, Enablers and Barriers for Consumer Engagement with Residential Demand Response. Energy Policy, 138, 111221.

5. Aurora. (2018). Power Sector Modelling: System Cost Impact of Renewables. Report for the National Infrastructure Commission. Oxford: Aurora Energy Research Limited.

6. Vivid Economics and Imperial College London. (2019). Accelerated Electrification and the GB Electricity System. Report 
Prepared for Committee on Climate Change. London: Committee on Climate Change.

7. COWI. (2016). Impact Assessment Study on Downstream Flexibility, Price Flexibility, Demand Response and Smart Metering. Brussels: European Commission DG Energy.

8. Grunewald, P., \& Diakonova, M. (2018). Flexibility, Dynamism and Diversity in Energy Supply and Demand: A Critical Review. Energy Res. Soc.l Sci., 38, 58-66.

9. Srivastava, A., Van Passel, S., \& Laes, E. (2018). Assessing the Success of Electricity Demand Response Programs: A MetaAnalysis. Energy Res. Soc.l Sci., 40, 110-117.

10. Directive (EU) 2019/944 of the European Parliament and of the Council of 5 June 2019 on common rules for the internal market for electricity and amending Directive 2012/27/EU (Text with EEA relevance.) PE/10/2019/REV/1 OJ L 158, 14.6.2019, p. 125-199.

11. Council of European Energy Regulators. (2019). Monitoring Report on the Performance of European Retail Markets in 2018. CEER Report. Available at https://www.ceer.eu/documents/104400/-/15c492f87-c88f-6c78-5852-43f1f13c89e4

12. Public Utilities Commission of Latvia. (2020). Energy Market Indicators 2020 Q2. Available at https://infogram.com/el_2020q2-1hnq41vl3gjp43z?live

13. Elektrum. (2021). Calculator of Electricity Products.Availableathttps://www.elektrum. lv/en/for-home/for-customers/products/

14. Alexela. (2021). Laiks mainīt elektrības piegādātāju. Available at https://www.alexela. lv/lv/pakalpojumi-un-cenas/elektribas-tarifiprivatpersonam

15. Nord Pool. (2021). Historical Market Data. Available at https://www.nordpoolgroup. com/historical-market-data/

16. EPRI. (2011). The Effect on Electricity Consumption of the Commonwealth Edison Customer Applications Program: Phase 2 Final Analysis. Palo Alto, CA: Electric Power Research Institute.

17. AECOM. (2011). Energy Demand Research
Project: Final Analysis. Hertfordshire: AECOM for Ofgem.

18. Allcott, H., (2011). Rethinking Real-Time Electricity Pricing. Spec. Sect. : Sustain. Res. Use Econ. Dyn., 33 (4), 820-842.

19. Dütschke, E., \& Paetz, A.-G. (2013). Dynamic Electricity Pricing - Which Programs do Consumers Prefer? Energy Policy, 59, 226-234.

20. Carmichael, R., Schofield, J., Woolf, M., Bilton, M., Ozaki, R. \& Strbacet, G. (2014). Residential consumer attitudes to timevarying pricing. London: Imperial College London.

21. Torstensson, D., \& Wallin, F. (2014). Exploring the Perception for Demand Response among Residential Consumers. Energy Procedia, 61, 2797-2800.

22. US DOE. (2014). Experiences from the consumer behaviour studies on engaging customers. Washington, DC: US Department of Energy.

23. Broka, Z., Kozadajevs, J., Sauhats, A., Finn, D. P., \& Turner, W. J. N. (2016). Modelling residential heat demand supplied by a local smart electric thermal storage system. Paper presented at the 2016 57th International Scientific Conference on Power and Electrical Engineering of Riga Technical University, RTUCON 2016, doi:10.1109/ RTUCON.2016.7763128 Retrieved from www.scopus.com

24. Hall, N.L., Jeanneret, T.D., \& Rai, A. (2016). Cost-Reflective Electricity Pricing: Consumer Preferences and Perceptions. Energy Policy, 95, 62-72.

25. Bird, J. (2015). Developing the smarter grid: The role of domestic and small and medium enterprise customers. Newcastleupon-Tyne.

26. Lebosse, C. (2016). Assessment of the social behaviour of the residential customers after on site tests. Grid4EU DEMO6 - dD6.8-1.

27. Bartusch, C., Odlare, M., Vassileva, I.N., Wallin, F., \& Wester, L. (2011). Introducing a Demand-Based Electricity Distribution Tariff in the Residential Sector: Demand Response and Customer Perception. Energy Policy, 39 (9), 5008-5025. 
28. Bradley, P., Coke, A., \& Leach, M. (2016). Financial Incentive Approaches for Reducing Peak Electricity Demand, Experience from Pilot Trials with a UK Energy Provider. Energy Policy, 98, 108-120.

29. Friis, F., \& Haunstrup Christensen, T. (2016). The Challenge of Time Shifting Energy Demand Practices: Insights from Denmark. Energy Res. Soc.l Sci., 19, 124133.

30. Capehart, B.L., Kennedy, W.J., Turner, W.C. (2008). Guide to energy management. (Fifth ed.). Atlanta, US: The Fairmont Press, Inc.

31. Central Statistical Bureau. (2016). EPM210. Mājokḷos izmantotās elektroierīces un elektroierīču vidējais vecums. Available at https://data1.csb.gov.lv/pxweb/lv/vide/ vide_energetika_energ_pat/EPM210.px/ Lecamwasam, L. (2012). Guide to Best Practice Maintenance \& Operation of HVAC Systems for Energy Efficiency. National Strategy on Energy Efficiency. Australia: Department of Climate Change and Energy Efficiency. Available at https:// www.airah.org.au/imis 15 prod/Content Files/UsefulDocuments/DCCEE HVAC HESS GuideToBestPractice2012.PDF

32. Tavakkoli, M., Fattaheian-dehkordi, S., Pourakbari-kasmaei, M., Liski, M., \& Lehtonen, M. (2019). An Incentive Based Demand Response by HVAC Systems in Residential Houses. Proceedings of 2019 IEEE PES Innovative Smart Grid Technologies Europe (ISGT-Europe) (pp. 1-5), 29 September 2019-2 October 2019, Bucharest, Romania. doi:10.1109/ isgteurope.2019.8905691
33. Petrie, C., Gupta, S., Rao, V., \& Nutter, B. (2018). Energy Efficient Control Methods of HVAC Systems for Smart Campus. 2018 IEEE Green Technologies Conference (GreenTech). DOI:10.1109/GREENTECH.2018.00032 Perez, K.X., Baldea, M., \& Edgar, T.F. (2016). Integrated Smart Appliance Scheduling and HVAC Control for Peak Residential Load Management. In 2016 American Control Conference (ACC), (pp. 1458-1463), 6-8 July 2016, Boston, Massachusetts, USA.

34. LVG̣MC.(2021). Datumeklēšana.Available at https://www.meteo.lv/meteorologija-datumeklesana/?nid $=461$

35. Petrichenko, R., Baltputnis, K., Sauhats, A., \& Sobolevsky, D. (2017). District Heating Demand Short-Term Forecasting. In 17th IEEE International Conference on Environment and ElectricalEngineering and 2017 1st IEEE Industrial and Commercial Power Systems Europe, EEEIC/I and CPS Europe 2017, 6-9 June 2017, Milan, Italy. DOI:10.1109/EEEIC.2017.7977633 